\title{
IMIDACLOPRID SEED TREATMENTS FOR THE CONTROL OF SPRINGTAILS IN SEEDLING BRASSICAS
}

\author{
P.J. ADDISON ${ }^{1}$ and P.W. FISHER ${ }^{2}$
}

\author{
${ }^{1}$ AgResearch, Ruakura Research Centre, Private Bag 3123, Hamilton \\ ${ }^{2}$ Bayer New Zealand Ltd, CPO Box 2825, Auckland \\ Corresponding author: paul.addison@agresearch.co.nz
}

\begin{abstract}
Two pot trials and two field trials were conducted to evaluate imidacloprid seed treatments for springtail control in forage brassica seedlings. Imidacloprid at rates from 1.75 to $21.0 \mathrm{~g}$ ai $/ \mathrm{kg}$ seed reduced garden springtail (Bourletiella hortensis) and lucerne flea (Sminthurus viridis) numbers by $68-88 \%$ relative to the untreated controls. Springtail damage was reduced and seedling establishment enhanced. Imidacloprid proved as or more effective than furathiocarb or thiodicarb seed treatments and phorate granules. Imidacloprid seed treatment had no adverse effect on either brassica germination or early seedling growth.
\end{abstract}

Keywords: imidacloprid, seed treatments, forage brassicas, Bourletiella hortensis, Sminthurus viridis.

\section{INTRODUCTION}

Insect damage during the germination and seedling stages can be responsible for poor establishment of forage brassica crops. Lowe (1956) reported on surveys which indicated around half of all brassica crops suffered moderate to severe damage by insects, chiefly weevils (Listronotus bonariensis and Irenimus spp.), grass grub beetles (Costelytra zealandica) and springtails (Bourletiella spp.). While several species of Bourletiella may cause damage to seedling brassicas, garden springtail (B. hortensis (Fitch) (Collembola: Sminthuridae)) is regarded as the most common (Ferro 1976). Another springtail, lucerne flea (Sminthurus viridis L. (Collembola: Sminthuridae)), can damage forage brassica crops sown after pasture (P.J. Addison, unpubl. data). Studies by Cleland (1955) suggested that springtail numbers as low as $215 / \mathrm{m}^{2}$ can cause significant damage to germinating brassicas.

Insecticides applied as seed treatments, granules at planting or sprays at seedling emergence can control springtail populations and improve seedling establishment (Cleland 1955; French \& Douglas 1967; Addison \& Welch 1994). Coating forage brassica seed with a systemic insecticide is now common practice in New Zealand.

This paper reports on trials evaluating imidacloprid, a highly systemic chloronicotinyl insecticide, as a seed treatment for springtail control in forage brassica crops.

\section{Pot trials}

\section{METHODS}

In two pot trials imidacloprid (Gaucho $70 \mathrm{WS}$ ), thiodicarb (Larvin $75 \mathrm{WP}$; Trial 1) or furathiocarb (Promet $400 \mathrm{CS}$; Trial 2) seed treatments (Table 1) were applied to single seed lines of kale (Brassica oleracea acephala, cv. Maris Kestral) (Trial 1) or turnip seed (Brassica campestris rapifera cv. Early Red) (Trial 2). Thiodicarb or furathiocarb were applied at their recommended rates as standards. The insecticides were applied to $50 \mathrm{~g}$ of brassica seed using a micro-rotating drum mixer. Water $(0.5 \mathrm{ml}$ per $50 \mathrm{~g}$ seed $)$ was added for all imidacloprid and thiodicarb treatments, but not for furathiocarb. For each treatment in both trials, three rows of three seeds were sown into each of four replicate $16 \mathrm{~cm}$ square pots containing insect-free Horotiu sandy loam soil. Sowing occurred on 30 November 1993 (Trial 1) and 8 March 1994 (Trial 2). The pots were placed in a randomised block design in a screenhouse maintained at ambient conditions.

New Zealand Plant Protection 55:317-321 (2002) 
In Trial 1, at 5 days post-sowing, 150 garden springtails and 30 lucerne fleas were confined in each pot with mesh covers. In Trial 2, 100 lucerne fleas were confined in each pot at 2 days post-sowing. After 7 days confinement, the surviving springtails in each trial were collected using a modified vacuum cleaner, killed in $70 \%$ alcohol and counted under a binocular microscope. Surviving seedlings in the pots were counted and removed and the number of springtail feeding scars on the stem and both surfaces of the cotyledons counted under a binocular microscope.

\section{Field trials}

Insecticide seed treatments (Table 3) were applied to a single seed line of forage brassica seed (rape x turnip hybrid, cv. Pasja) by International Seed Coaters, Palmerston North. In both trials, the seed was sown with a precision cone seeder into a seed bed cultivated from glyphosate (Roundup, $1.44 \mathrm{~kg}$ ai $/ \mathrm{ha}$ ) treated pasture. Sowing rate was $3.0 \mathrm{~kg} / \mathrm{ha}$. For the phorate treatment $(1 \mathrm{~kg}$ ai/ha), granules (Thimet $20 \mathrm{G}$ ) were applied with untreated brassica seed. Sowing occurred on 21 November 1994 at Te Mawhai, near Te Awamutu (Trial 3) and 23 November 1994 at Kaipaki, near Hamilton (Trial 4). In both trials each treatment was replicated four times in a randomised complete block design. Plots were $6 \mathrm{~m}$ long by $1.2 \mathrm{~m}$ ( 8 seed rows) wide.

At 14 (Trial 4) or 16 (Trial 3) days post-sowing, seedling numbers in the central two rows of each plot were counted and 10 randomly selected seedlings were cut at ground level and placed in plastic bags. In the laboratory springtail feeding scars on the seedlings were counted.

At 97 (Trial 3) or 99 (Trial 4) days post-sowing, all plants in two randomly selected $1 \mathrm{~m}$ lengths of row/plot were harvested at ground level and oven dried for $48 \mathrm{~h}$ at $96^{\circ} \mathrm{C}$ to determine dry matter yields.

Statistical Analysis

The data from all trials were analysed using analysis of variance in MINITAB (Version 9.0). Individual treatment means were separated using least significant difference values.

\section{Pot trials}

\section{RESULTS}

In Trial 1, compared to the untreated seed all insecticide seed treatments reduced both garden springtail and lucerne flea numbers $(\mathrm{P}<0.001)$ (Table 1$)$. There was no rate effect of imidacloprid and all rates displayed a similar efficacy to the standard, thiodicarb. In all insecticide treatments the number of seedlings remaining at the conclusion of the

TABLE 1: Mean number of live garden springtail and lucerne flea remaining after 7 days on forage brassica seedlings grown in pots. Seed was treated with imidacloprid, furathiocarb or thiodicarb.

\begin{tabular}{lccccc}
\hline & $\begin{array}{c}\text { Application } \\
\text { rate }\end{array}$ & \multicolumn{2}{c}{ Trial 1 } & & Trial 2 \\
\cline { 3 - 4 } \cline { 5 - 5 } Treatment & (g ai/kg seed) & $\begin{array}{c}\text { Garden } \\
\text { springtail }\end{array}$ & Lucerne flea & & Lucerne flea \\
\hline untreated & - & $73.5 \mathrm{a}^{1}$ & $7.8 \mathrm{a}$ & & $58.8 \mathrm{a}$ \\
imidacloprid & 1.75 & - & - & & $8.8 \mathrm{~b}$ \\
imidacloprid & 3.5 & $16.3 \mathrm{~b}$ & $1.5 \mathrm{~b}$ & & $7.3 \mathrm{~b}$ \\
imidacloprid & 7.0 & $16.0 \mathrm{~b}$ & $2.5 \mathrm{~b}$ & & $8.5 \mathrm{~b}$ \\
imidacloprid & 14.0 & $14.5 \mathrm{~b}$ & $1.8 \mathrm{~b}$ & & - \\
imidacloprid & 21.0 & $18.8 \mathrm{~b}$ & $2.0 \mathrm{~b}$ & & - \\
thiodicarb & 19.5 & - & - & $20.8 \mathrm{~b}$ \\
furathiocarb & 5.0 & 12.2 & 2.3 & & 16.4 \\
LSD (P<0.05) & & & & &
\end{tabular}

${ }^{1}$ Means followed by the same letter within columns are not significantly different. 
trial was not different from untreated seed (Table 2). All insecticide seed treatments were equally effective in reducing both the number of seedlings damaged by springtails $(\mathrm{P}<0.05)$ and the number of feeding scars on each surviving seedling $(\mathrm{P}<0.001)$ relative to the untreated seed (Table 2).

TABLE 2: Seedling establishment and springtail feeding damage on forage brassica seedlings growing in pots after treatment of seed with imidacloprid, furathiocarb or thiodicarb.

\begin{tabular}{|c|c|c|c|c|c|c|c|}
\hline \multirow[b]{2}{*}{ Treatment } & \multirow{2}{*}{$\begin{array}{l}\text { Application } \\
\text { rate } \\
\text { (g ai/kg } \\
\text { seed) }\end{array}$} & \multicolumn{2}{|c|}{$\begin{array}{l}\text { Mean number } \\
\text { of seedlings } \\
\text { established }^{1}\end{array}$} & \multicolumn{2}{|c|}{$\begin{array}{l}\text { Mean number } \\
\text { of seedlings } \\
\text { with springtail } \\
\text { damage }^{2}\end{array}$} & \multicolumn{2}{|c|}{$\begin{array}{l}\text { Mean number } \\
\text { of springtail } \\
\text { feeding scars } \\
\text { per damaged } \\
\text { seedling }\end{array}$} \\
\hline & & Trial 1 & Trial 2 & Trial 1 & Trial 2 & Trial 1 & Trial 2 \\
\hline untreated & - & $8.0 \mathrm{a}^{3}$ & $4.8 \mathrm{a}$ & $8.0 \mathrm{a}$ & $7.5 \mathrm{a}$ & $5.3 \mathrm{a}$ & $8.1 \mathrm{a}$ \\
\hline imidacloprid & 1.75 & - & $6.8 \mathrm{abc}$ & - & $7.3 \mathrm{a}$ & - & $4.0 \mathrm{c}$ \\
\hline imidacloprid & 3.5 & - & $7.5 \mathrm{bc}$ & - & $6.8 \mathrm{a}$ & - & $2.9 \mathrm{c}$ \\
\hline imidacloprid & 7.0 & $7.0 \mathrm{a}$ & $8.0 \mathrm{bc}$ & $5.3 \mathrm{~b}$ & $5.8 \mathrm{a}$ & $2.5 \mathrm{~b}$ & $2.8 \mathrm{c}$ \\
\hline imidacloprid & 14.0 & $7.8 \mathrm{a}$ & $8.3 \mathrm{c}$ & $4.5 \mathrm{~b}$ & $6.8 \mathrm{a}$ & $1.8 \mathrm{~b}$ & $2.6 \mathrm{c}$ \\
\hline imidacloprid & 21.0 & $7.0 \mathrm{a}$ & - & $4.8 \mathrm{~b}$ & - & $2.2 \mathrm{~b}$ & - \\
\hline thiodicarb & 19.5 & $7.5 \mathrm{a}$ & - & $5.5 \mathrm{~b}$ & - & $2.5 \mathrm{~b}$ & - \\
\hline furathiocarb & 5.0 & - & $6.0 \mathrm{ab}$ & - & $6.5 \mathrm{a}$ & - & $5.8 \mathrm{~b}$ \\
\hline LSD $(\mathrm{P}<0.05)$ & & 1.6 & 2.1 & 2.2 & 1.8 & 1.4 & 1.4 \\
\hline
\end{tabular}

Number of seedlings out of 9 seeds sown.

${ }^{2}$ Numbers include those seedlings killed by springtail damage.

${ }^{3}$ Means followed by the same letter within columns are not significantly different.

In Trial 2, all seed treatments reduced lucerne flea numbers $(\mathrm{P}<0.001)$ relative to the untreated seed (Table 1). There was no rate effect of imidacloprid and all rates displayed a similar efficacy to the standard, furathiocarb. Imidacloprid applied at 3.5 $(\mathrm{P}<0.05), 7.0(\mathrm{P}<0.01)$ and $14.0(\mathrm{P}<0.001) \mathrm{g} / \mathrm{kg}$ seed significantly enhanced seedling establishment (Table 2), while furathiocarb did not enhance seedling establishment relative to untreated seed. The number of seedlings with lucerne flea feeding damage, including those killed, was similar in all treated and untreated seed. However, the number of feeding scars on surviving seedlings was reduced by imidacloprid $(\mathrm{P}<0.001$; all rates) and furathiocarb $(\mathrm{P}<0.01)$ compared to scar numbers on untreated seedlings (Table 2). All rates of imidacloprid were more effective than furathiocarb at reducing the number of lucerne flea feeding scars/surviving seedling $(\mathrm{P}<0.05,1.75 \mathrm{~g} / \mathrm{kg}$ seed; $\mathrm{P}<0.01$, all other rates).

Imidacloprid seed treatment had no adverse effect on either brassica germination or early seedling growth (data not shown).

Field trials

Seedling numbers and dry matter yields were similar for all treatments in both Trial 3 and Trial 4 (Table 3). In Trial 3 all rates of imidacloprid seed treatment and phorate granules were equally effective in reducing the number of seedlings with springtail damage compared to untreated and furathiocarb treated seed $(\mathrm{P}<0.01)$ (Table 4). Furathiocarb did not reduce the number of seedlings with springtail damage, but did reduce the number of feeding scars/damaged seedling compared to untreated seedlings $(\mathrm{P}<0.01)$ (Table 4). All rates of imidacloprid and phorate reduced the number of feeding scars/damaged seedling compared to untreated seedlings $(\mathrm{P}<0.001)$ and furathiocarb treated seedlings $(\mathrm{P}<0.05)$ 
TABLE 3: Forage brassica seedling numbers and dry matter yields in the field after imidacloprid or furathiocarb seed treatments or application of phorate granules.

\begin{tabular}{|c|c|c|c|c|c|}
\hline \multirow[b]{2}{*}{ Treatment } & \multirow[b]{2}{*}{ Application rate } & \multicolumn{2}{|c|}{$\begin{array}{c}\text { Mean number of } \\
\text { seedlings }{ }^{1}\end{array}$} & \multicolumn{2}{|c|}{$\begin{array}{l}\text { Mean dry matter yields }{ }^{2} \\
\text { (tonnes/ha) }\end{array}$} \\
\hline & & Trial 3 & Trial 4 & Trial 3 & Trial 4 \\
\hline untreated & - & $166.5 \mathrm{a}^{3}$ & $169.5 \mathrm{a}$ & $8.93 \mathrm{a}$ & $9.43 \mathrm{a}$ \\
\hline imidacloprid & $7.0 \mathrm{~g} \mathrm{ai} / \mathrm{kg}$ seed & $186.0 \mathrm{a}$ & $175.0 \mathrm{a}$ & $8.83 \mathrm{a}$ & $10.10 \mathrm{a}$ \\
\hline imidacloprid & $14.0 \mathrm{~g} \mathrm{ai} / \mathrm{kg}$ seed & $172.0 \mathrm{a}$ & $153.5 \mathrm{a}$ & $9.50 \mathrm{a}$ & $11.50 \mathrm{a}$ \\
\hline imidacloprid & $17.5 \mathrm{~g} \mathrm{ai} / \mathrm{kg}$ seed & $178.3 \mathrm{a}$ & $183.0 \mathrm{a}$ & $8.77 \mathrm{a}$ & $10.49 \mathrm{a}$ \\
\hline furathiocarb & $5.0 \mathrm{~g} \mathrm{ai} / \mathrm{kg}$ seed & $166.8 \mathrm{a}$ & $158.0 \mathrm{a}$ & $8.80 \mathrm{a}$ & $10.57 \mathrm{a}$ \\
\hline phorate & $1.0 \mathrm{~kg}$ ai/ha & $166.5 \mathrm{a}$ & $156.0 \mathrm{a}$ & $9.70 \mathrm{a}$ & $10.87 \mathrm{a}$ \\
\hline LSD $(\mathrm{P}<0.05)$ & & 40.7 & 34.6 & 2.03 & 2.87 \\
\hline
\end{tabular}

${ }^{1}$ Numbers counted at 14 (Trial 4) or 16 (Trial 3) days post-sowing.

${ }^{2}$ Dry matter yields measured at 97 (Trial 4) or 99 (Trial 3) days post-sowing.

${ }^{3}$ Means followed by the same letter within columns are not significantly different.

In Trial 4 the number of seedlings with springtail damage was reduced relative to untreated seed only by imidacloprid applied at 14.0 and $17.5 \mathrm{~g} / \mathrm{kg}$ seed $(\mathrm{P}<0.01$ and $\mathrm{P}<0.05$ respectively) and phorate granules $(\mathrm{P}<0.01)$ (Table 4$)$. However, all insecticide treatments were equally effective in reducing the number of feeding scars/damaged seedling compared to seedlings arising from untreated seed (Table 4).

TABLE 4: Springtail feeding damage on forage brassica seedlings growing in the field. Seed was treated with imidacloprid or furathiocarb or was sown with phorate granules.

\begin{tabular}{|c|c|c|c|c|c|}
\hline \multirow[b]{2}{*}{ Treatment } & \multirow[b]{2}{*}{ Application rate } & \multicolumn{2}{|c|}{$\begin{array}{l}\text { Mean number of } \\
\text { seedlings with } \\
\text { springtail damage }^{1}\end{array}$} & \multicolumn{2}{|c|}{$\begin{array}{c}\text { Mean number of } \\
\text { springtail feeding scars } \\
\text { per damaged seedling }\end{array}$} \\
\hline & & Trial 3 & Trial 4 & Trial 3 & Trial 4 \\
\hline untreated & - & $10.0 \mathrm{a}^{2}$ & $9.8 \mathrm{a}$ & $8.3 \mathrm{a}$ & $9.9 \mathrm{a}$ \\
\hline imidacloprid & $7.0 \mathrm{~g} \mathrm{ai} / \mathrm{kg}$ seed & $4.5 \mathrm{~b}$ & $8.5 \mathrm{ab}$ & $2.5 \mathrm{c}$ & $4.4 \mathrm{~b}$ \\
\hline imidacloprid & $14.0 \mathrm{~g} \mathrm{ai} / \mathrm{kg}$ seed & $5.5 \mathrm{~b}$ & $6.5 \mathrm{bc}$ & $1.8 \mathrm{c}$ & $2.8 \mathrm{~b}$ \\
\hline imidacloprid & $17.5 \mathrm{~g}$ ai $/ \mathrm{kg}$ seed & $5.0 \mathrm{~b}$ & $7.0 \mathrm{bc}$ & $2.1 \mathrm{c}$ & $2.8 \mathrm{~b}$ \\
\hline furathiocarb & $5.0 \mathrm{~g} \mathrm{ai} / \mathrm{kg}$ seed & $9.1 \mathrm{a}$ & $8.8 \mathrm{ab}$ & $5.0 \mathrm{~b}$ & $5.4 \mathrm{~b}$ \\
\hline phorate & $1.0 \mathrm{~kg}$ ai $/ \mathrm{ha}$ & $4.0 \mathrm{~b}$ & $5.8 \mathrm{c}$ & $2.3 \mathrm{c}$ & $2.9 \mathrm{~b}$ \\
\hline LSD $(\mathrm{P}<0.05)$ & & 2.6 & 2.3 & 2.2 & 3.2 \\
\hline
\end{tabular}

${ }^{1}$ Out of 10 seedlings assessed at 14 (Trial 4) or 16 (Trial 3) days post-sowing.

${ }^{2}$ Means followed by the same letter within columns are not significantly different.

\section{DISCUSSION}

The pot trials clearly showed that all insecticide seed treatments increased mortalities of both garden springtail and lucerne flea, with reductions of $68-88 \%$ relative to numbers feeding on untreated seedlings. All rates of imidacloprid were as efficacious as the standard seed treatments, furathiocarb or thiodicarb. The seed treatments may have given greater reductions in springtail numbers if weeds had been controlled. Volunteer weed seedlings emerging in the pots provided favourable alternative host plants, with many being severely defoliated. 
Damage visually observed during the pot trials was similar to that previously reported (Cleland 1955; French \& Douglas 1967; Ferro 1976). Damage began as soon as the seed shell was shed and the stem exposed prior to the complete emergence of the cotyledons above ground. Stem damage at this stage of seedling development occurred in Trial 2 and resulted in seedling mortality. Damage to the cotyledons first appeared as slight scalloping on the leaf edges or as small pits or shot holes in the leaf. Damage to the untreated seedlings increased rapidly with some cotyledons completely destroyed. All seed treatments proved effective at reducing springtail damage in the pot trials.

Although no definitive sampling was undertaken in the field trials, springtails (both Bourletiella spp. and lucerne flea) were the only pests observed in sufficient numbers to cause measurable damage. All damage observed on seedlings removed from the field trials was consistent with the springtail damage observed in the pot trials. Under field conditions, the imidacloprid seed treatments evaluated were as effective as phorate granules and more effective than furathiocarb seed treatment for reducing springtail damage in forage brassica seedlings. While damage did occur, seedling numbers and dry matter yields were similar in all treatments, including untreated controls, indicating that springtail numbers were below the economic damage threshold.

Imidacloprid, applied at $7.2 \mathrm{~g} / \mathrm{kg}$ seed, is now registered in New Zealand as a seed treatment for the control of springtails and other insect pests in forage brassicas. The results of this work support the claim that imidacloprid is an effective protectant against springtails in forage brassicas, with no apparent phytotoxicity.

\section{ACKNOWLEDGEMENTS}

We thank P. Bardoul and D. Black for allowing us to conduct trials on their farms, P. Bertram for assistance with the seedling counts and N. Cox for assistance with statistical analysis of the data.

\section{REFERENCES}

Addison, P.J.; Welsh, R.D. 1994: Furathiocarb seed treatment for the control of springtails on seedling brassicas. Proc. 47th N.Z. Plant Prot. Conf.: 135-138.

Cleland, J.W. 1955: Distribution and control of springtails in cruciferous crops and pastures. N.Z. J. Agric. 91: 13-16.

Ferro, D.N. 1976: Forage and seed crop pests. In: Ferro D.N. ed. New Zealand Insect Pests. Lincoln University College of Agriculture, Canterbury, New Zealand. p. 137.

French, R.A.; Douglas, J.A. 1967: Control of insect pests of establishing brassicas. Proc. 20th N.Z. Weed and Pest Control Conf: : 179-184.

Lowe, A.D. 1956: Control of insect pests on brassica crops in New Zealand. N.Z. J. Agric. 93: 341-353. 